\title{
A cross-sectional screening survey on the seroprevalence of hepatitis B and hepatitis C amongst the general population of rural districts of Sindh, Pakistan
}

\author{
Muhammad Sohaib ASGHAR ${ }^{1}$, Uzma RASHEED ${ }^{2}$, Maira HASSAN², Mohammed AKRAM $^{2}$, \\ Rabail YASEEN ${ }^{1}$ and Basmah FAYAZ $^{2}$
}

Received: 23 June 2020 Accepted: 22 November 2020

\begin{abstract}
Background - Viral hepatitis is a global phenomenon, with the disease burden varying on a daily basis. Amongst chronic infections, hepatitis B virus and hepatitis $\mathrm{C}$ virus (HCV) are egregiously linked to severe health-related complications, with a worldwide prevalence of 248 million and 71 million respectively. Amongst the developing world, a hand full of countries are exhibiting a gross decline in chronic viral infection prevalence, like Bangladesh. While countries such as India have a consistent prevalence, Pakistan bears one of the largest proportions of chronic viral hepatitis globally with increasing trends shown year-by-year. Various old literature texts have stated an approximate national prevalence rate around $2.6 \%$ and $5.3 \%$ of hepatitis B and C respectively. Objective - The objective of this study was to determine the current seroprevalence rates of chronic viral hepatitis amongst the general population of rural Sindh using a screening program to determine the current disease burden. Methods - An observational, cross-sectional survey based on a screening program was conducted in 5 districts with a combined population of over 6.5 million. The screening was carried out via the administration of various camps with the assistance of local social workers and welfare organizations. A total of $24,322 \mathrm{individuals}$ met the inclusion criteria and were screened through $(\mathrm{HBs} \mathrm{Ag} / \mathrm{HCV}$ ) rapid test cassette (WC) Imu-Med one-step diagnostic test. Results - Hepatitis B was found positive in 964 (3.96\%) individuals including 421 (43.67\%) males and $543(56.32 \%)$ females, while hepatitis C was positive in $2872(11.80 \%)$ individuals including 1474 (51.32\%) males and 1398 (48.67\%) females. The prevalence amongst the districts varied between $0.97 \%$ and $9.06 \%$ for hepatitis B, and $1.61 \%$ and $29.50 \%$ for hepatitis C, respectively. Umerkot was found to be the most prevalent district amongst rural Sindh, while Badin had the least number of seropositive people. The second most prevalent district of the study population was found to be Tando Allahyar followed by Mirpur Khas. The combined seroprevalence of $15.76 \%$ was calculated for hepatitis B and C together amongst the five studied districts of rural and peri-urban Sindh. Conclusion - The alarmingly high prevalence rates revealed in our study warrant the urgent need to generate multiple effective strategies in the region to enhance awareness amongst the general population regarding screening, prevention, and prompt treatment of the disease. Keywords - Hepatitis B; hepatitis C; screening; population; public health; prevalence; epidemiology.
\end{abstract}

\section{INTRODUCTION}

Hepatitis $\mathrm{B}$ virus (HBV) and hepatitis $\mathrm{C}$ virus (HCV) are chronic diseases with severe health complications and a worldwide prevalence of 248 million and 71 million respectively ${ }^{(1-4)}$. Approximately more than 500 million individuals suffer from hepatitis B and hepatitis $\mathrm{C}$ infections rendering it a leading global health dilemma ${ }^{(5)}$. According to the World Health Organization (WHO) annual proportion of individuals suffering globally from hepatitis $\mathrm{B}$ infection is 2 billion $^{(4,6)}$. Hepatitis $\mathrm{C}$ depicted as a debilitating disease has an annual global proportion of 3-4 million individuals suffering from $\mathrm{it}^{(5,7)}$. The global prevalence rate of death according to the WHO recorded for hepatitis B is 0.6 million $^{(6-8)}$. The death toll recorded for hepatitis $\mathrm{C}$ as per the WHO is 0.4 million per year ${ }^{(7,9)}$. The percentage of incidence of hepatitis $\mathrm{B}$ virus infecting the general population in the continent of Asia as certified by WHO is $2.0 \%$ to $7.0 \%$ but can rise in highly endemic areas ${ }^{(10)}$. Hepatitis $\mathrm{C}$ infection has deep roots engraved in the region of Asia with a percentage of $2.8 \%$ of people suffering from $i^{(11)}$. Prevalence of hepatitis B is categorized into three numerical categories, namely high $(>8 \%)$, intermediate $(2-7 \%)$, and low $(<2 \%)^{(12)}$.

Amongst the countries residing within the subcontinent region, hepatitis B is highly endemic in China with a prevalence percentage of $7-20 \%$ among the general population ${ }^{(12,13)}$. While hepatitis $\mathrm{C}$ infection is significantly less prevalent at a percentage of $1.6 \%{ }^{(14)}$. The percentage prevalence of hepatitis B infection detected within the general population of Afghanistan is 1.9\%, proffering it as low prevalent in the region compared to China ${ }^{(15)}$. Analogizing the viruses together, a prevalence of $0.7-1.1 \%$ was calculated among individuals of Afghanistan suffering from hepatitis $\mathrm{C}^{(15,16)}$. Hepatitis B is hypo-

Declared conflict of interest of all authors: none

Disclosure of funding: no funding received

Research performed at: Dow University Hospital, Karachi, Pakistan

${ }^{1}$ Dow University of Health Sciences, Karachi, Pakistan. ${ }^{2}$ Liaquat National Hospital and Medical College, Karachi, Pakistan

Corresponding author: Dr. Muhammad Sohaib Asghar. E-mail: sohaib_asghar123@yahoo.com 
endemic in Iran accounting for a $1.7 \%$ prevalence ${ }^{(17)}$. Epidemiology of hepatitis $\mathrm{C}$ frequency calculated within the general community of Iran is $0.3 \%$, evincing it as low endemic ${ }^{(18)}$. Saudi Arabia has a hepatitis B epidemiological frequency rate detected at 1.31 percent, categorizing it as low within the country ${ }^{(19)}$. The periodicity of hepatitis $\mathrm{C}$ infection amongst the Saudi population is reported at $0.4-1.7 \% 0^{(19,20)}$. Bangladesh is leading towards a decline in the prevalence percentage of hepatitis B infection among healthy citizens, accounting for 4\% or less in recent intervals ${ }^{(21)}$. Data quoting the prevalence of hepatitis $\mathrm{C}$ among the healthy individuals of Bangladesh is limited and provides an estimation of $0.2-1 \%$ prevalence which is low endemic in the country ${ }^{(22,23)}$. India, in terms of the prevalence incidence rate of hepatitis B within healthy individuals, marks itself in the intermediate zone $(2-7 \%)$ accounting for $4 \%$ of the disease load ${ }^{(24)}$. Comparisons to hepatitis $\mathrm{C}$ prevalence reveal a drastic change, as studies showed only $1 \%$ of the total Indian population to be infected with it ${ }^{(3)}$.

The national survey of the Pakistan Medical Research Council (PMRC) concluded the incidence prevalence rate of HBV in the general population at $2.5 \%$, categorizing it in the intermediate zone of prevalence, affecting 9 million healthy individuals across the country ${ }^{(4,6,8)}$. Intra-provincial prevalence of hepatitis B as detected by PMRC states infection rates as 2.4\% in Punjab, 2.5\% in Sindh, $4.3 \%$ in Balochistan, and 4.3\% in Khyber Pakhtunkhwa ${ }^{(6,8)}$. HCV infects 10 million healthy individuals making it an epidemiological infection across the country ${ }^{(4,7)}$. Hepatitis $\mathrm{C}$ infection is quoted to have the second-highest prevalence in Pakistan all over the globe with an estimated $5.0-6.2 \%$ prevalence incidence rate denoting it as intermediate zone disease ${ }^{(7)}$. The distribution of prevalence incidence rates of hepatitis $\mathrm{C}$ infection within the country reveal Punjab at 5.46\%, Khyber Pakhtunkhwa at $6.07 \%$, Balochistan at $25.77 \%$, and Sindh at $2.55 \%$, respectively ${ }^{(7,25)}$.

The objective of this study was to determine the current seroprevalence rates of chronic viral hepatitis amongst the general population of rural Sindh. We identified five distinct districts of rural Sindh, where the seroprevalence data was either not available, or scarcely reported in the literature. A screening of the general population was the prime target of this study to report the current disease burden of chronic viral hepatitis amongst the masses of remote village areas of Sindh.

\section{METHODS}

An observational, cross-sectional survey based on a screening program was conducted in five districts of rural and peri-urban Sindh primarily targeting the rural population. Those five districts included Badin, Tando Allahyar, Mirpur Khas, Umerkot, and Thatta (including Tehsil Kandiaro) with a combined population of over 6.5 million $(6,522,681)$. The particular data of each district being studied is described in TABLE 1 .
Ethical approval was obtained for the study from the institutional Ethical Review Committee. The screening was carried out through the administration of various camps with the assistance of local social workers and welfare organizations. The general public was made aware of the timings and 75 different venues for screening camps via distributing pamphlets and spreading the word through local places of worship. The study included all the healthy, asymptomatic individuals of age between 5 and 80 years, who had not previously been screened or diagnosed with hepatitis, and those who were willing to participate. Individuals with a documented history of hepatitis B or C, patients with previously prescribed hepatitis treatment, people who were below 5 or above the age of 80 years, and those not willing to participate were excluded from the study. During the screening survey, verbal consent was obtained from all individuals.

The screening was done by using $\mathrm{HBsAg} / \mathrm{HCV}$ rapid test cassette (WC) Imu-Med one-step diagnostic test, with a sensitivity of $97.1 \%$ and specificity of $99.9 \%$ according to the manufacturer, which got stored at 2-30 degree Celcius (36-86 degree Fahrenheit). This diagnostic kit was sealed for in vitro diagnostic use by Healgen scientific LLC 3818, Fuqua street Houston TX, 77047, USA. Individuals found positive for either hepatitis B or C serology were referred to tertiary care set up for further evaluation and management.

\section{Characteristics of the districts included in the study population}

Badin: this district was established in 1975, it lies to the east of River Indus, comprising of five tehsils and 46 union councils, populated around 1,136,636 in 1998 (16.42\% urban, $83.58 \%$ rural) which increased to $1,804,516$ (21.74\% urban, $78.36 \%$ rural) according to 2017 census, amongst whom $51.67 \%$ are males and $48.32 \%$ females. The total area of the district is 6,726 square kilometers. The sample size was calculated via the Rao-soft digital sample size calculator (http://www.raosoft.com/samplesize.html), with a population size of $1.804,516$, a confidence level of $99 \%$, response distribution of $50 \%$, and error of margin of $0.96 \%$. There were a total of 10,371 individuals screened from Badin district from 31 screening camps, 4,603 of them being males, and 5,768 females.

Tando Allahyar: this district comprises three tehsils and 20 union councils. It is populated around 836,887 as per the 2017 census, increasing from 493,526 in 1998. It consists of an urban population of $31.28 \%$ and a rural of $68.72 \%$, a male population of $51.70 \%$, and females were $48.28 \%$. The sample size was calculated via Rao-soft digital sample size calculator (http://www.raosoft.com/samplesize. $\mathrm{html}$ ), with a population size of 836,887 , a confidence level of $99 \%$, response distribution of $50 \%$, and error of margin of $1.50 \%$. A total of 4273 individuals were screened from this district from 16 screening camps, comprising of 2076 males and 2197 females.

TABLE 1. Showing the general characteristics of the studied districts.

\begin{tabular}{lccccc}
\hline District & Badin & TandoAllahyar & Mirpur Khas & Umerkot & Thatta + Kandiaro \\
\hline Total population & $1,804,516$ & 836,887 & $1,505,876$ & $1,073,146$ & $979,817+322,439$ \\
$\quad$ Male & 932,488 & 432,746 & 778,172 & 557,557 & $510,279+168,972$ \\
Female & 871,979 & 404,112 & 727,650 & 515,569 & $469,504+153,467$ \\
& & & & & \\
Total screened & 10371 & 4273 & 8611 & 783 & 284 \\
Male & 4603 & 2076 & 3650 & 287 & 115 \\
Female & 5768 & 2197 & 4961 & 496 & 169 \\
\hline
\end{tabular}


Mirpur Khas: mirpur Khas district is located in the southeastern quadrant of Sindh, consisting of a population of 1,505,876, with $51.67 \%$ being males and $48.32 \%$ females. The urban population comprises of $28.27 \%$ while the remaining rural population is $71.72 \%$. The sample size was calculated via a Rao-soft digital sample size calculator (http://www.raosoft.com/samplesize.html), with a population size of $1,505,876$, a confidence level of $99 \%$, response distribution of $50 \%$, and error of margin of $1.05 \%$. A total of 3650 males and 4961 females were screened in this district through 19 screening camps, making a total of 8611 individuals.

Umerkot: this district consists of 4 tehsils and populated around $1,073,146$ according to the 2017 census. Amongst them, $51.95 \%$ are males and $48.04 \%$ are females, $77.32 \%$ rural population and $22.67 \%$ are urban. The previous census showed an increasing population from 383,020 (1981) to 664,797 (1998) respectively. The sample size was calculated via the Rao-soft digital sample size calculator (http://www.raosoft.com/samplesize.html), with a population size of $1,073,146$, a confidence level of $99 \%$, response distribution of $50 \%$, and error of margin of $3.50 \%$. There was a total of 783 individuals screened from this district via 6 screening camps, with 287 of them being males, and 496 females.

Thatta district + tehsil Kandiaro: Thatta is located in southern Sindh comprising of 4 tehsils, with a population of 979,817 consisting of $52.07 \%$ males and $47.91 \%$ females. It comprises $82.03 \%$ rural and $17.97 \%$ urban population. Tehsil Kandiaro is a part of Naushehro Feroze District consisting of a population of 322,439. The combined sample size was calculated via the Rao-soft digital sample size calculator (http://www.raosoft.com/samplesize.html), with a population size of $1,302,256$, a confidence level of $90 \%$, response distribution of $50 \%$, and error of margin of $5.81 \%$. A total of 284 individuals were screened through two screening camps at Thatta district and one in tehsil Kandiaro, comprising of 115 male participants and 169 females.

\section{Statistical methods}

The Statistical Package for the Social Sciences, SPSS (version 25.0) was used for the measurement of frequency and percentage distributions amongst the study population.

\section{RESULTS}

This study was conducted as an observational, cross-sectional, screening program in five districts and one tehsil, in the province of Sindh, Pakistan. A total of around 6.5 million population was targeted in these five districts. 75 screening camps were deployed throughout the districts specifically targeting the rural population, and the general public was made aware of the timings and place of the screening via a spread of word in local places of worship and distribution of pamphlets beforehand amongst the masses.

A total of 24,322 individuals met the inclusion criteria and were screening through $\mathrm{HBsAg} / \mathrm{HCV}$ rapid test cassette (WC) Imu-Med one-step diagnostic test. Out of them, 10,731 were males (44.12\%) and 13,591 were females $(55.87 \%)$. Hepatitis B was found positive in 964 individuals (3.96\% of the study population), while hepatitis C was positive in 2872 individuals ( $11.80 \%$ of the study population). Amongst them, both hepatitis $\mathrm{B}$ and $\mathrm{C}$ positivity were present in 203 individuals ( $0.83 \%$ of the study population). Hence, the total prevalence of $15.76 \%$ was calculated for hepatitis B and hepatitis $\mathrm{C}$ combined amongst the five studied districts of rural and urban Sindh, as shown in TABLE 2.
TABLE 2. Showing demographic data of the study population.

\begin{tabular}{lc}
\hline Study population & $\begin{array}{c}\text { Around } 6.5 \\
\text { million }\end{array}$ \\
\hline Total individuals screened & 24,322 \\
Males & $10731(44.12 \%)$ \\
Females & $13591(55.87 \%)$ \\
Hepatitis B positivity & $964(3.96 \%)$ \\
Males & 421 \\
Females & 543 \\
Hepatitis C positivity & $2872(11.80 \%)$ \\
Males & 1474 \\
Females & 1398 \\
Both HBV and HCV simultaneously positive & $203(0.83 \%)$ \\
Males & 154 \\
Females & 49 \\
\hline
\end{tabular}

The prevalence amongst the male population was estimated to be $3.92 \%$ for hepatitis B and $13.73 \%$ for hepatitis C in the study population. The prevalence amongst females was found to be $3.99 \%$ for hepatitis B and $10.28 \%$ for hepatitis C, respectively. Amidst the total of 10,731 males screened, $1,895(17.65 \%)$ were infective from either HBV or HCV. While 1,941 (14.28\%) out of 13,591 females screened were infective. The territorial distribution of prevalence is shown in TABLE 3. Umerkot was found to be the most prevalent district amongst rural Sindh with the respective rates of $9.06 \%$ for hepatitis B and $29.50 \%$ for hepatitis C. Least prevalent district amongst the study population was Badin with a prevalence rate of $0.97 \%$ for hepatitis B and $1.61 \%$ for hepatitis C, respectively. The gender distribution of each district was also shown in TABLE 3. The second most prevalent district of the study population was found to be Tando Allahyar with an overall prevalence of 5.73\% for hepatitis B and $24.87 \%$ for hepatitis C, followed by Mirpur Khas. The cumulative prevalence and male to female proportions of each district have been illustrated in FIGURES 1, 2, 3, and 4.

\section{DISCUSSION}

Hepatitis B and C are globally identified chronic infections that remain dormant for many years' even decades. At least $60 \%$ of all liver cancers are attributed to late diagnosis and treatment of these viral illnesses. Awareness regarding the surveillance and treatment of these insidiously replicating chronic infections is the most important interstice needed to be permeated in order to achieve the global elimination goal of chronic hepatitis. Viral hepatitis is a global phenomenon, with the disease burden varying on a daily basis. WHO gives a prevalence rate of $1.0 \%$ for hepatitis $\mathrm{C}$, with a previously reported increase from $2.3 \%$ to $2.8 \%$ between 1990 and 2005 , according to the Global Burden of diseases, injuries, and risk factors $2010^{(26,27)}$. Many studies have revealed an increasing prevalence of hepatitis B amongst specific risk groups like medical waste handlers, blood donors, and reproductive age ${ }^{(5,28,29)}$. Amongst the developing world, a hand full of countries are exhibiting a gross decline in chronic viral infections prevalence, like Bangladesh is showing a decreasing trend of prevalence towards chronic viral infections, with rates of $0.2 \%$ to $0.7 \%$ in recent studies ${ }^{(30,31)}$. While 
TABLE 3. Showing district-wise distribution of positive cases along with gender proportions amongst the study population.

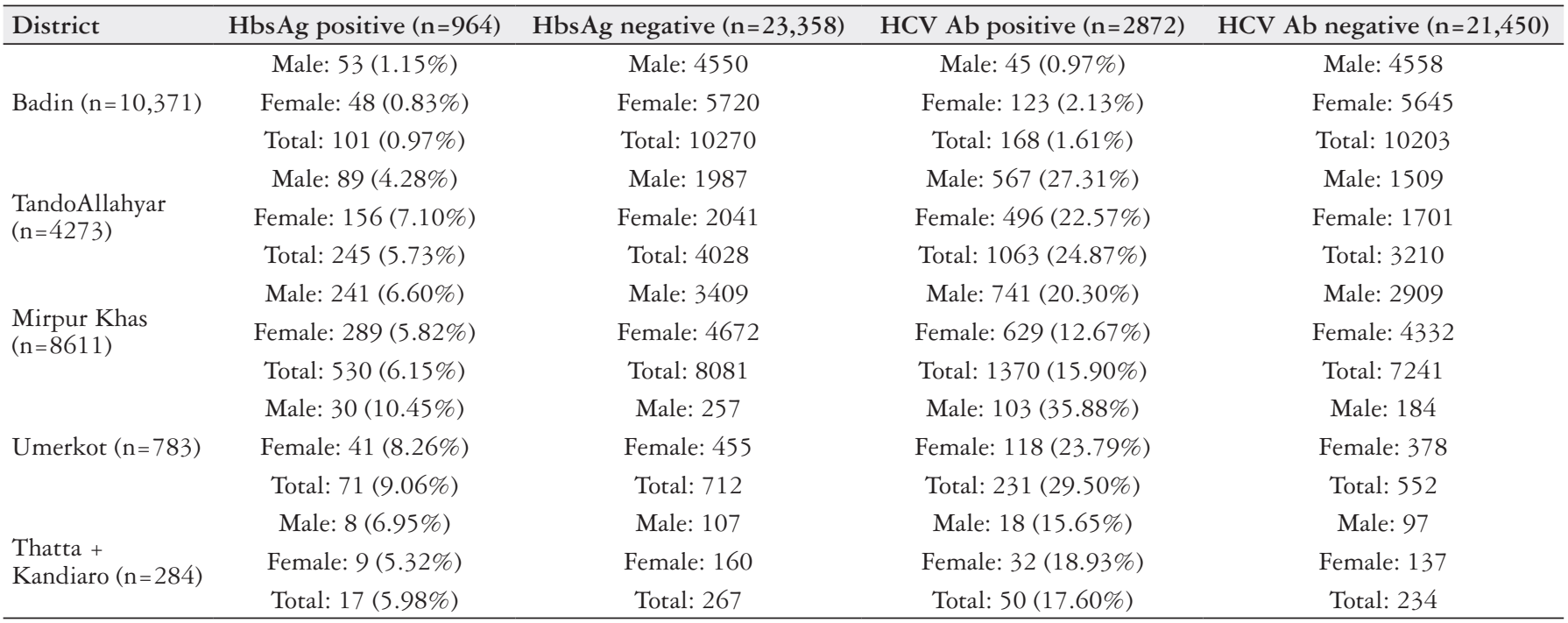

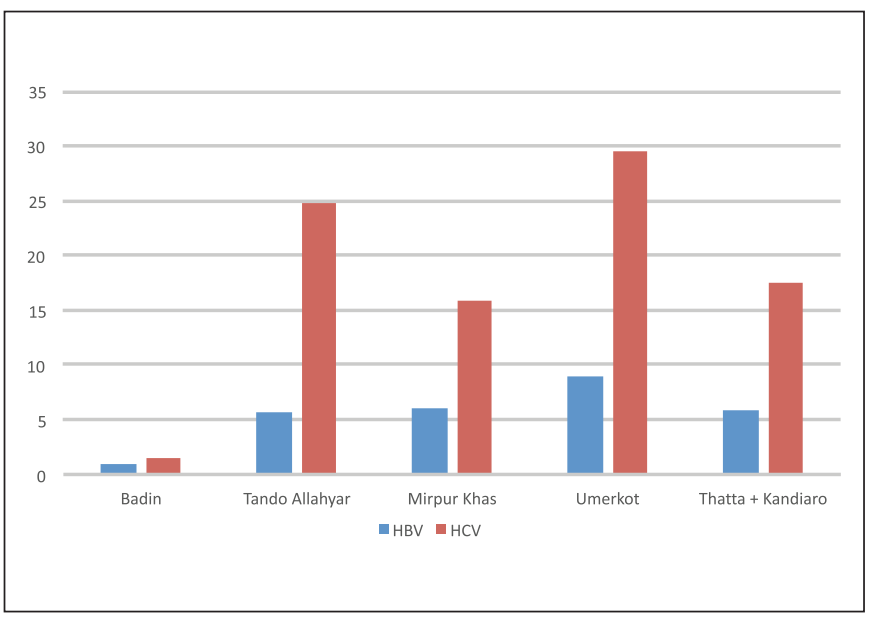

FIGURE 1. District-wise prevalence of HBV and HCV.

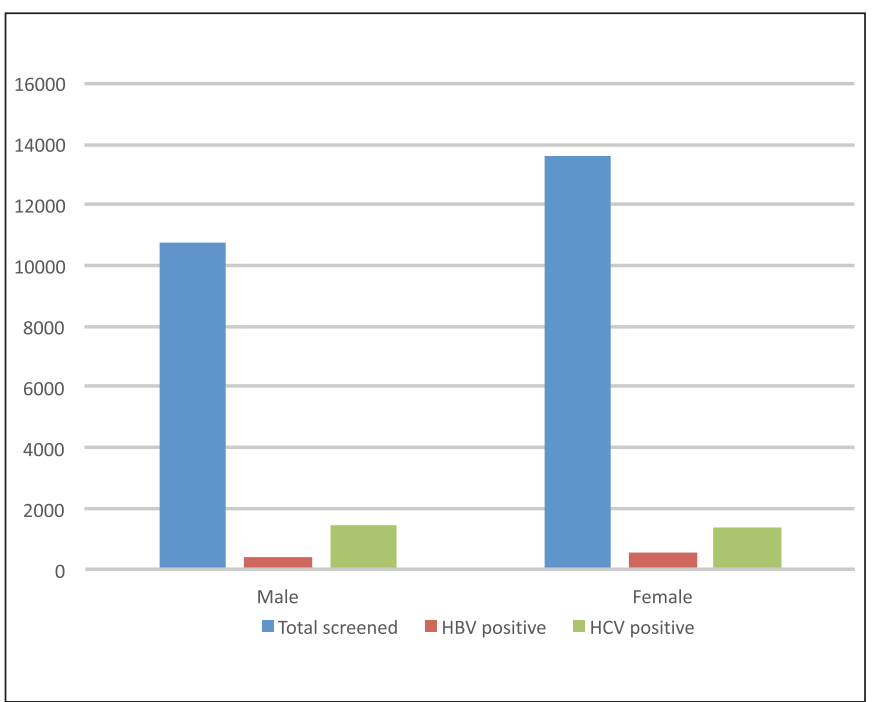

FIGURE 3. Proportion of screened population infected.

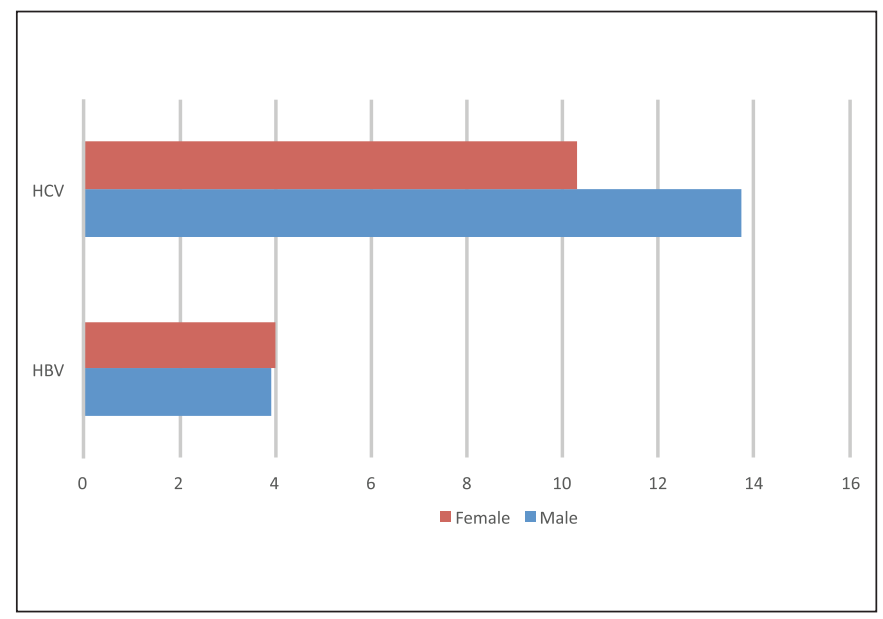

FIGURE 2. Gender proportions amongst HBV and HCV.

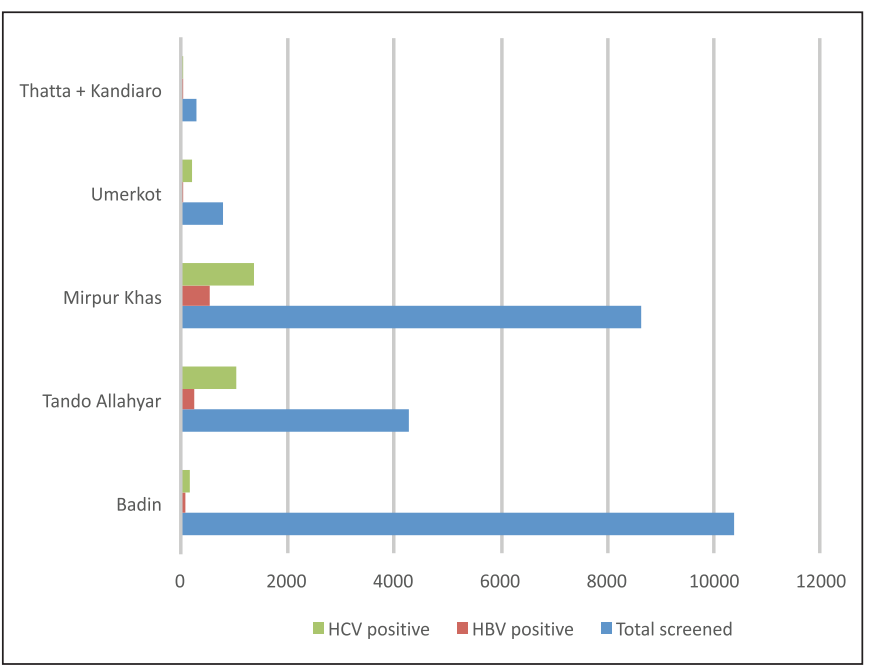

FIGURE 4. Proportion of screened individual found infective amongst the districts. 
countries such as India have a consistent prevalence of $1.63 \%$ for hepatitis B and 0.3 to $3.6 \%$ for hepatitis C. Pakistan bears one of the largest proportions of chronic viral hepatitis in the world, with increasing trends shown year-by-year ${ }^{(32-37)}$.

Various old literature texts have stated a national prevalence rate of around $2.6 \%$ and $5.3 \%$ of hepatitis $\mathrm{B}$ and $\mathrm{C}$ respectively ${ }^{(25,38)}$. Hence, we aimed a study to calibrate fresh prevalence rates of chronic viral hepatitis targeted amongst the population of rural Sindh. Five distinct districts of rural and peri-urban areas of Sindh were screened for the presence of viral hepatitis. The results of our study showed an overwhelming presence of screening positive people in some districts compared to others. The national prevalence rates of hepatitis $\mathrm{C}$ was surpassed by our study with the results of $11.80 \%$ amongst the 24,322 individuals screened, while that of hepatitis B was comparable, $3.96 \%$ with respect to $2.6 \%$ reported previously ${ }^{(25,34-38)}$.

A similar study was carried out in Kech district, Balochistan; which determined a prevalence of $5.5 \%$ for hepatitis C infection with a higher rate identified in males ${ }^{(39)}$, as compared with our study which showed a higher prevalence of male population $(13.73 \%)$ in contrast to females $(10.28 \%)$. While another study in Balochistan screened hepatitis B in 7 districts, enrolling 15260 individuals, and accumulated a prevalence rate of $9.8 \%$ ranging between $3.3 \%$ and $17.0 \%$ amongst distinct districts ${ }^{(40)}$. In our study, the prevalence of hepatitis B ranged between $0.97 \%$ (lowest) in Badin and $9.06 \%$ (highest) in Umerkot and that of hepatitis C ranging between 1.61\% (lowest) in Badin and 29.50\% (highest) in Umerkot.

Comparing our deductions to previously conducted studies in rural and urban Sindh, Z Abbas et al conducted a study in 2008 at Jarwar, a rural part of district Sukkur and concluding a prevalence rate of 5\% for hepatitis B (comparable with our study), and 33.7\% for hepatitis C (drastically higher than our study) ${ }^{(41)}$. In 2008, another similar study was conducted at district Naushehro Feroze, amongst the population of two remote villages of rural Sindh, and compared it with a peri-urban area Gharo, a subdivision of district Thatta $^{(42)}$. The study depicted a much higher rate of prevalence in rural areas (7.0\% and $28.6 \%$ respectively) in contrast to peri-urban prevalence (3.1\% and $3.9 \%$ respectively). Our study also showed similar results, with Umerkot being the highest prevalent district amongst rural Sindh, and Badin being a peri-urban area has the lowest prevalence.

A retrospective analysis was conducted in the rural district of Tando Muhammad Khan, concluding a positivity of $8 \%$ and $17 \%$ for hepatitis $\mathrm{B}$ and $\mathrm{C}$ respectively, with results showing higher rates among men as compared to women, the results were slightly comparable with our study with a higher ratio ${ }^{(43)}$. Lastly, the district of Tando Allahyar was previously studied for determining risk factors of hepatitis $\mathrm{C}$, giving a female to male ratio of $2: 1$ ( $64 \%$ females, and $36 \%$ males), the distribution was contrasting to our study where the prevalence of hepatitis $\mathrm{C}$ in Tando Allahyar district is estimated to be $24.87 \%$ with $27.31 \%$ being males and $22.57 \%$ females $^{(44)}$. All these results indicated an overall increasing seroprevalence of hepatitis B surface antigen (HbsAg) and hepatitis $\mathrm{C}$ antibody (Anti-HCV) in comparison to the previous studies conducted in the region.
Limitations of our study include a lack of determining risk factors amongst the study population. It is postulated that many studies have been conducted in the past over this region establishing a list of various risk factors and behaviors leading to such higher prevalence rates in the region. Thus, we opted for an allout approach for screening and determining current prevalence rates rather than identifying any more risk factors from the study population. Secondly, previous studies gave ample data about certain age groups being infected more from hepatitis viruses, we do not emphasize or categorize different age groups. The study also did not perform confirmatory serological tests or molecular tests to evaluate viremia, making it ominous that our research is a seroprevalence study of $\mathrm{HBsAg}$ and anti-HCV.

\section{CONCLUSION}

In general, Pakistan has a high prevalence rate for chronic viral hepatitis, and the figures vary amongst districts, regions, and provinces. Rural districts of Sindh are lacking current statistics on the prevalence of viral hepatitis, hence we identified five such districts of rural Sindh, where the prevalence data was scarcely reported in the literature. The alarmingly high seroprevalence rates revealed in our study warrant the urgent need to administer multiple effective strategies in the region to enhance awareness amongst the general population regarding screening, prevention, and prompt treatment of the disease.

\section{ACKNOWLEDGEMENTS}

We would like to thank Dr. Nazish Butt and Dr. Amanullah Abbasi for sharing with us the vital data for this research.

\section{Authors' contribution}

Asghar MS: the concept and design of the study. Hassan M, Rasheed $U$ and Yaseen R: data acquisition. Akram M, Asghar MS and Rasheed U: statistical analysis. Hassan M and Fayaz B: performed the interpretation of the results. Hassan M and Yaseen R: analyzed the data and drafted the manuscript. Yaseen R and Fayaz $\mathrm{B}$ : revising it critically for important intellectual content. Rasheed $\mathrm{U}$ and Akram M: final approval of the version to be published. Asghar MS: guarantor of the article.

All authors critically revised the manuscript, approved the final version to be published, and agree to be accountable for all aspects of the work. All the authors agreed to be accountable for all aspects of the work in ensuring that questions related to the accuracy or integrity of any part of the work are appropriately investigated and resolved.

\section{Orcid}

Muhammad Sohaib Asghar: 0000-0001-6705-2030.

Uzma Rasheed: 0000-0003-0596-7766.

Maira Hassan: 0000-0001-6092-0552.

Mohammed Akram: 0000-0003-0252-2032.

Rabail Yaseen: 0000-0001-5762-6707.

Basmah Fayaz: 0000-0002-9714-0530. 
Asghar MS, Rasheed U, Hassan M, Akram M, Yaseen R, Fayaz B. Um levantamento transversal sobre a soroprevalência da hepatite B e hepatite C entre a população geral dos distritos rurais de Sindh, Paquistão. Arq Gastroenterol. 2021;58(2):150-6.

RESUMO - Contexto - A hepatite viral é um fenômeno global, com a intensidade da doença variando diariamente. Entre as infecções crônicas, o vírus da hepatite $\mathrm{B}$ e o vírus da hepatite $\mathrm{C}(\mathrm{VHC})$ estão fortemente ligados a complicações graves relacionadas à saúde, com prevalência mundial de 248 milhões e 71 milhões, respectivamente. Entre o mundo em desenvolvimento, uma quantidade de países está exibindo um declínio bruto na prevalência de infecção viral crônica, tal como Bangladesh. Embora países como a Índia tenham uma prevalência consistente, o Paquistão tem uma das maiores proporções globais de hepatite viral crônica, com tendências crescentes mostradas ano a ano. Vários textos da menos recentes têm declarado uma taxa de prevalência nacional aproximada em torno de 2,6\% e 5,3\% da hepatite B e C, respectivamente. Objetivo - O objetivo deste estudo foi determinar as atuais taxas de soroprevalência da hepatite viral crônica entre a população geral do Sindh rural utilizando um programa de triagem para determinar a carga atual da doença. Métodos - Foi realizada uma pesquisa observacional e transversal baseada em um programa de triagem combinada em cinco distritos com população de mais de 6,5 milhões. A triagem foi realizada por meio da administração de diversos acampamentos com o auxílio de assistentes sociais locais e organizações de assistência social. Um total de 24.322 indivíduos atenderam aos critérios de inclusão e foram examinados através do teste rápido (HBsAg/VHC) Imu-Med em uma etapa. Resultados - Hepatite B positiva foi encontrada em 964 (3,96\%) indivíduos incluindo $421(43,67 \%)$ homens e $543(56,32 \%)$ mulheres, enquanto hepatite $\mathrm{C}$ foi positiva em $2.872(11,80 \%)$ indivíduos incluindo $1.474(51,32 \%)$ homens e 1.398 (48,67\%) mulheres. A prevalência entre os distritos variou entre $0,97 \%$ e $9,06 \%$ para hepatite B, e 1,61\% e 29,50\% para hepatite C, respectivamente. Umerkot foi encontrado como o distrito mais prevalente entre Sindh rural, enquanto Badin tinha o menor número de pessoas soropositivas. O segundo distrito mais prevalente da população de estudos foi encontrado como Tando Allahyar, seguido por Mirpur Khas. A soroprevalência combinada de 15,76\% foi calculada para hepatite B e C em conjunto entre os cinco distritos estudados do Sindh rural e periurbano. Conclusão - As taxas de prevalência alarmantemente reveladas em nosso estudo justificam a necessidade urgente de gerar múltiplas estratégias efetivas na região para aumentar a conscientização da população em geral sobre rastreamento, prevenção e tratamento rápido da doença.

Palavras-chave - Hepatite B; hepatite C; triagem; população; saúde pública; prevalência; epidemiologia.

\section{REFERENCES}

1. Mason LMK, Veldhuijzen IK, Duffell E, Ahee AV, Bunge EM, Amato-Gauci AJ, Tavoschi L. Hepatitis B and C testing strategies in healthcare and community settings in the EU/EEA: A systematic review. J Viral Hepat. 2019:1431-3. DOI: $10.1111 /$ jvh.13182.

2. Botheju WSP, Zghyer F, Mahmud S, Terlikbayeva A, El-Bassel N, Abu-Raddad LJ. The epidemiology of hepatitis C virus in Central Asia: Systemic review, meta-analyses, and meta-regression analyses. Scientific reports. 2019; 9:1-15. DOI: 10.1038/s41598-019-38853-8.

3. Pradip B, Subhadip P. Current profile of Hepatitis C in Tripura, India. Int J Sci Study. 2019;7:1-4.

4. Mehmood S, Raza H, Abid F, Saeed N, Rehan HM, Javed S, et al. National prevalence rate of hepatitis $\mathrm{B}$ and $\mathrm{C}$ in Pakistan and its risk factors. J Public Health (Berl.). 2020;28:751-64. DOI: 10.1007/s10389-019-01081-5.

5. Uddin MS, Islam N, Khan MEU, Yeasmin S, Ahmed F, Amiruzzaman M. Frequency of hepatitis $\mathrm{B}$ and $\mathrm{C}$ viral infections among the medical waste handlers. BMC Infect Dis. 2017;4:3-9. DOI: 10.3329/bjid.v4i1.37673.

6. Khan N, Ali F, Bahadar S, Rehman KU, Aziz A, Akbar NU, et al. Prevalence of hepatitis B viral infection in Punjab province of Pakistan. Pakistan J Zool 2017;49:1511-3. DOI: 10. 17582/journal.pjz/2017.49.4.sc4.

7. Ahsan A, Khan AZ, Javed H, Mirza S, Chaudhry SU, Hassan SSU. Estimation of hepatitis $\mathrm{C}$ prevalence in the Punjab province of Pakistan: A retrospective study on general population. PLOS One. 2019;14:1-12. DOI: 10.1371/journal. pone. 0214435 .

8. Raza A, Saleem M, Afzal MS. The first report of hepatitis B virus prevalence in Skardu, Gilgit Baltistan. A neglected area of Pakistan. Jundishapur J Microbiol. 2018;11:1-3. DOI: 10.5812/jjm.62352.

9. Akhtar N, Ilyas M, Muhammad K, Shams S, Saeed K, Asadullah. Prevalence of hepatitis $\mathrm{C}$ virus infections among the general population of Buner, Khyber Pakhtunkhwa, Pakistan. Biomed Res Ther. 2016;3:1003-17. DOI: 10.15419/ bmrat.v3i12.139.

10. Martinelli D, Fortunato F, Simsek G, Prato R. Epidemiology and Prevention of Viral Hepatitis B and C. Practical Management of Chronic Viral Hepatitis. Gaetano Serviddio, IntechOpen. 2013. DOI: 10.5772/55870. [Internet]. Available from: https://www.intechopen.com/books/practical-management-of-chronic-viral-hepatitis/epidemiology-and-prevention-of-viral-hepatitis-b-and-c.

11. Petruzziello A, Marigliano S, Loquercio G, Cozzolino A, Cacciapuoti C. Globa epidemiology of hepatitis $\mathrm{C}$ virus infection: An up-date of the distribution and circulation of hepatitis C virus genotypes. World J Gastroenterol. . 2016;22:782440. DOI: 10.3748/wjg.v22.i34.7824
12. Hou J, liu Z, Gu F. Epidemiology and prevention of hepatitis B virus infection. Int J Med Sci. 2005;2:50-7. DOI: 10.7150/ijms.2.50. Epub 2005 Jan 5.

13. Andre F. Hepatitis B epidemiology in Asia, the Middle East and Africa. Elsevier vaccine. 2000;18 (Suppl 1):S20-2. DOI: 10.1016/s0264-410x(99)00456-9.

14. Bennet H, Waser N, Johnston K, Kao JH, Lim YS, Duan ZP, et al. A review of burden of hepatitis C virus infection in China, Japan, South Korea and Taiwan. Hepatol Int. 2015;1-14. DOI:10.1007/s12072-015-9629-x.

15. Khan S, Attaullah S. Share of Afghanistan populace in hepatitis B and hepatitis C infection's pool: is it worthwhile. Virol J. 2011;8:216. DOI: 10.1186/1743422X-8-216.

16. Chemaitelly H, Mahmud S, Rahmani AM, Abu-Raddad LJ. The epidemiology of hepatitis $\mathrm{C}$ virus in Afghanistan: systemic review and meta- analysis. Int $\mathbf{J}$ Infect Dis. 2015;40:54-63. DOI: 10.1016/j.ijid.2015.09.011.

17. Poorolajal J, Majdzadeh R. Prevalence of chronic hepatitis B infection in Iran: a review article. J Res Med Sci. 2009;14:249-58.

18. Mahmud S, Akbarzadeh V, Abu-Raddad LJ. The epidemiology of hepatitis C virus in Iran: Systemic review and meta- analyses. Sci Rep. 2018;8:1-25. DOI: 10.1038/s41598-017-18296-9.

19. Abdo AA, Sanai FM, Al-Faleh FZ. Epidemiology of viral hepatitis in Saudi Arabia: Are we off the hook? Saudi J Gastroenterol. 2012;18:349-57. DOI: 10.4103/1319-3767.103425.

20. Daw MA, Dau AA. Hepatitis C virus in Arab world: A state of concern. Scientific World Journal. 2012:1-12. DOI: 10.1100/2012/719494.

21. Uz-Zaman H, Rahman A, Yasmin M. Epidemiology of hepatitis B virus infection in Bangladesh: Prevalence among general population, risk groups and genotype distribution. Genes. 2018;9:1-16. DOI: 10.3390/genes9110541.

22. Al-Mahtab M. Past, present, and future of viral hepatitis in Bangladesh. Euroasian J Hepatogastroenterol. 2016;6:43-4. DOI: 10.5005/jp-journals-10018-1164.

23. Al-Mahtab M, Rahman S, Karim F, Foster G, Solaiman S. Epidemiology of Hepatitis C Virus in Bangladeshi General Population. Hepatobiliary Pancreat Dis Int. 2009;2:14-7. DOI: 10.3329/bsmmuj.v2i1.3705.

24. Ray G. Current scenario of hepatitis B and its treatment in India. J Clin Transl Hepatol. 2017.5:277-96. DOI: 10.14218/JCTH.2017.00024.

25. Arshad A, Ashfaq UA. Epidemiology of hepatitis C infection in Pakistan: Current Estimate and major risk factors. Crit Rev Eukaryot Gene Expr. 20172:63-77. DOI: 10.1615/critRevEukaryotGeneExpr.2017018935.

26. Felisberto M, Saretto AA, Wopereis S, Machado MJ, Spada C. Prevalence of $\mathrm{HCV}$ infection in a prison population of the greater Florianópolis area. Rev Soc Bras Med Trop. 2019;52:20190143. DOI: 10.1590/0037-8682-0143-2019. 
27. Mohd Hanafiah K, Groeger J, Flaxman AD, Wiersma ST. Global epidemiology of hepatitis $\mathrm{C}$ virus infection: New estimates of age-specific antibody to $\mathrm{HCV}$ seroprevalence. Hepatology. 2013;57:1333-42. DOI: 10.1002/hep.26141

28. Nazar H, Nadia N, Shazia N, Zulfiqar A, Farhat A. Prevalence of Hepatitis B and Hepatitis C in blood donors of Karachi. Biomedica. 2008;24:116-7. [Internet] Available from: http://thebiomedicapk.com/articles/132.pdf

29. Javed N, Naz S. Prevalence of Hepatitis B infection in married women of child bearing age in district Islamabad. Gomal Med J Sci. 2013;11:216-9.

30. Nadim Hasan K, Khaleque MA, Anjum Shejuti N, Wasi T, Islam S. Prevalence of Hepatitis B Virus Seromarkers and Associated Risk Factors in Young Healthy Individuals in Bangladesh: Implications for Preventive Strategies. Hepat Mon 2017;17:14245. DOI: 10.5812/hepatmon. 14245 .

31. Ashraf H, Alam NH, Rothermundt C, Brooks A, Bardhan P, Hossain L, et al Prevalence and risk factors of hepatitis $\mathrm{B}$ and $\mathrm{C}$ virus infections in an impoverished urban community in Dhaka, Bangladesh. BMC Infect Dis. 2010;10:208. DOI: 10.1186/1471-2334-10-208. PMID: 20630111.

32. Sood A, Suryaprasad A, Trickey A, Kanchi S, Midha V, Foster MA, et al. The burden of hepatitis $\mathrm{C}$ virus infection in Punjab, India: A population-based serosurvey. PLoS One. 2018;13:0200461. DOI: 10.1371/journal.pone.0200461. PMID: 30048454

33. Shanmugam Rengasamy P, Selvakumarb B, Hemalathac V, Vivekanandan S Prevalence of hepatitis B and hepatitis $\mathrm{C}$ infection from a population-based study in Southern India. Hepatology. 2018;30:1344-51. DOI: 10.1097/ MEG.0000000000001180

34. Qureshi H, Bile KM, Jooma R, Alam SE, Afridi HU. Prevalence of hepatitis B and $\mathrm{C}$ viral infections in Pakistan: findings of a national survey appealing for effective prevention and control measures. East Mediterr Health J. 2010;16(Suppl):S15-23. PMID: 21495584. Available from: htp://ecommons.aku.edu/pakistan_fs_mc_surg_surg/294
35. Ali SA, Donahue RM, Qureshi H, Vermund SH. Hepatitis B and hepatitis C in Pakistan: prevalence and risk factors. Int J Infect Dis. 2009;13:9-19. DOI: 10.1016/j.ijid.2008.06.019. PMID: 18835208.

36. Ali M, Idrees M, Ali L, Hussain A, Ur Rehman I, Saleem S, Afzal S, Butt S Hepatitis B virus in Pakistan: a systematic review of prevalence, risk factors, awareness status and genotypes. Virol J. 2011;8:102. DOI: 10.1186/1743-422X8-102. PMID: 21375760.

37. Al Kanaani Z, Mahmud S, Kouyoumjian SP, Abu-Raddad LJ. The epidemiology of hepatitis C virus in Pakistan: systematic review and meta-analyses. R Soc Open Sci. 2018;5:180257. DOI: 10.1098/rsos.180257. PMID: 29765698.

38. Bosan A, Qureshi H, Bile KM, Ahmad I, Hafiz R. A review of hepatitis viral infections in Pakistan. J Pak Med Assoc. 2010;60:1045-8.

39. Ahmed F, Irving W, Anwar M, Myles P, Neal K. Prevalence and risk factors for hepatitis C virus infection in Kech District, Balochistan, Pakistan: Most infections remain unexplained. A cross-sectional study. Epidemiol Infect. 2013;140:716-23. DOI: $10.1017 / \mathrm{S} 0950268811001087$

40. Sheikh NS, Sheikh AS, Sheikh AA, Yahya S, Rafi-U-Shan, Lateef M. Sero-prevalence of hepatitis B virus infection in Balochistan Province of Pakistan. Saudi J Gastroenterol. 2011;17:180-4. DOI: 10.4103/1319-3767.80380. PMID: 21546720.

41. Abbas Z, Jeswani NL, Kakepoto GN, Islam M, Mehdi K, Jafri W. Prevalence and mode of spread of hepatitis B and C in rural Sindh, Pakistan. Trop Gastroenterol. 2008;29:210-6.

42. Aziz S, Khanani R, Noorulain W, Rajper J. Frequency of hepatitis B and C in rural and periurban Sindh. J Pak Med Assoc. 2010;60:853-7.

43. Kumar A, Lalani S, Afridi AAK, Khuwaja AK. Screening of Hepatitis B and $\mathrm{C}$ among people visiting general practice clinics in a rural district of Sindh, Pakistan. J Ayub Med Coll Abbottabad 2010;22:143-5. Available from: http:// www.ayubmed.edu.pk/JAMC/PAST/22-4/Ameet.pdf

44. Channa N, Khan H. Risk factors for hepatitis C disease in Tando Allahyar, Pakistan: a case-control study. Bangladesh Rev Sci Med. 2011;10:163-9. DOI 10.3329/bjms.v10i3.8359. 